\title{
X-linked Ehlers-Danlos syndrome
}

INSERM

\section{Source}

INSERM. (1999). Orphanet: an online rare disease and orphan drug data base. $\underline{X \text {-linked }}$ Ehlers-Danlos syndrome. ORPHA:75497

Ehlers-Danlos syndromes (EDS) form a heterogeneous group of hereditary connective tissue diseases characterized by joint hyperlaxity, cutaneous hyperelasticity and tissue frag ility. EDS type $V$ is characterised by hyperextensible skin but tissue frag ility and joint hyperlaxity are mild. This form of EDS is very rare and has been described in only two families so far. Other reported features include cong enital heart disease, hernias and short stature. Transmission is X-linked recessive. 